\title{
Express Students' Problem Solving Skills from Metacognitive Skills Perspective on Effective Mathematics Learning
}

\author{
Mohamad Ariffin Abu Bakar*, Norulhuda Ismail \\ Faculty of Social Sciences and Humanities, School of Education, Universiti Teknologi Malaysia, Malaysia
}

Received December 28, 2019; Revised February 25, 2020; Accepted March 12, 2020

Copyright $\bigcirc 2020$ by authors, all rights reserved. Authors agree that this article remains permanently open access under the terms of the Creative Commons Attribution License 4.0 International License

\begin{abstract}
Measuring the standard of success in mathematics learning is whether students can apply mathematical concepts and solve mathematics problems completely. However, the ability of students in solving mathematics problems is sometimes limited to routine problems and when faced with non-routine and in the form of HOTs applications problems, there is complicatedness and difficulty in determining the solution. Therefore, this study aims to review systematically, which metacognitive skills are applied and practiced when students solve mathematics problems and also to clarify the effect of metacognitive skills on student's learning performance. Studies around 2006 and up to date have been explored based on approaches, methods, and practices of metacognitive skills implemented. A total of 12 articles were selected for analysis. This review shows that metacognitive skills are implied and practiced when students solve mathematics problems, but the metacognitive regulation subcomponents are more likely to affect the completeness of the solution than the metacognitive knowledge aspects. Metacognitive skills also have a positive impact on student learning. So, delivering effective learning is very reasonable and timely, and metacognitive skills are applied based on platforms for metacognitive learning strategy.
\end{abstract}

Keywords Problem-Solving Skills, Metacognitive Skills, Effective Mathematics Learning, Metacognitive Regulation, Metacognitive Knowledge

\section{Introduction}

Mathematical competencies are the ability of students to co-ordinate their cognition of mathematical concepts, knowledge, and skills in problem-solving [1-3] and can be transformed into a wider context [3-5]. The challenge to ensure that the goals are met is the weakness and the level of students' ability to solve mathematical problems, whether routine or non-routine questions [6,7]. Problem-solving skills are the student's ability to regulate and manage cognitive aspects [8]. This ability is based on the stimuli of the internal factor of self and external factors. According to Adnan \& Arsad Bahri [9], Menz \& Cindy Xin [10] and Stephanou \& Mpiontini [10] internal factors are related to existing cognitive settings, experience, and knowledge. If students are accustomed and trained to solve mathematical problems independently (minds-on), then the experience can influence the success $[12,13]$. The impact of positive experiences and current expertise improved by cognitive coordination will enhance the success of mathematics problem-solving [14,15]. The external factor refers to external stimuli that can induce students' activeness and willingness to solve problems $[3,16]$. The interests of the issues and problems discussed in the task and the situation delivered of the assignment are also influencing problem-solving skills as an external factor. According to Tzohar-Rozen \& Kramarski [17] and Smith \& Mancy [8], the appropriateness and attractiveness of the delivery or the solution of problem-solving activities are also factors affecting the problem-solving skills of the students.

To bridge the gap between the internal and external factors discussed, some analyses have shown that metacognitive skills are very significant and can meet the needs of reducing the problem of the low level of mathematics problem-solving skills $[3,4,11]$. According to Schraw \& Moshman [14] and Tzohar-Rozen \& Kramarski [17], metacognitive skills are a reference and act like an engine that can leverage student learning. Metacognitive skills are the mastery and implementation of metacognitive components that are metacognitive knowledge and metacognitive regulation [18,19]. Metacognitive 
knowledge includes subcomponents which are declarative, procedural and conditional, while metacognitive regulation includes planning, monitoring, and evaluation. According to Schraw \& Moshman [14], Tarricone [18] and Du Toit \& Du Toit [5] these two components influence learning but will give an impact separately and can move in or follow the order [20,21] and according to Tarricone [18], these metacognitive skills will form taxonomy to metacognition and thinking chronology during the learning process.

Metacognitive knowledge will stimulate emotional, motivational and previous knowledge of students to form problem-solving orientation [2]. This knowledge will create awareness of the good habit of learning, the necessary solution strategies and knowledge about the source of information to solve the problem [22]. The introduction of the activity and the presentation of the task will form an external stimulus which in turn will affect emotion and self-determination. This effect is an adaptation of metacognitive knowledge. Furthermore, to form behaviours and actions to solve the problem is the effect of metacognitive regulation on thinking procedure (process) and determine of solutions by managing, planning, monitoring and evaluating $[4,13,14,16]$. Just now, it is the metacognitive regulation acting on the internal factor of the learning. Students' skills in planning solutions, setting goals for solving, selecting strategies, acting on strategies, monitoring accuracy and reflecting findings will lead to perfection and accuracy in solving mathematical problems [2,9].

Therefore, simply by developing the student's metacognitive skills, mathematical problem-solving skills can be improved. However, specific research on how exactly this metacognitive skill affects the mathematical problem-solving skills and the details of the metacognitive components and subcomponents is a need. According to Stephanou \& Mpiontini [11], Tony Karnain et.al [12], Menz \& Cindy Xin [10], Smith \& Mancy [8] and Cera, Mancini \& Antonietti [23] metacognitive studies need to be continued to ensure metacognitive skills and strategies learning that applying metacognitive skills can contribute knowledge and ideas to generate intervention to learning, especially in scope of mathematical problem-solving. Tarricone [18] has outlined the metacognitive hierarchy and its existence based on one's thinking ability. However, in-depth studies of metacognitive skills as students solve mathematical problems are lacking. The discussion and relevance of mathematical problem solving and metacognitive skills also need to be clarified and proven by pieces of evidence [20]. More previous studies have focused on the correlation of mathematical problem solving to either metacognitive knowledge or metacognitive regulation, such as Desoete \& Roeyers [24], Kazemi, Fadaee \& Bayat [7], Abdullah,

Rahman \& Hamzah [6], Van Der Stel, Veenman, Deelen \& Haenan [15], but do not in detail focus on how these metacognitive skills work and act during mathematical problem-solving steps.

\section{Methodology}

This review is to determine which metacognitive skills are applied and practiced when students solve mathematics problems and to study the effect of metacognitive skills on student's mathematical learning performance. To achieve the objectives, the research questions were created as follows:

1. What are metacognitive skills that students applied during the mathematical problems solving task

2. What is the effect of metacognitive skills on the student's learning performance

The procedures and designs of this study are in the form of surveys by conducting systematic review based on the implementation of Preferred Reporting Items for Systematic Reviews and Meta-Analyses (PRISMA) proposed by Moher et al [25], on studies that deal with the effectiveness and influences of metacognitive on mathematical problems or mathematics learning in general. The journal or article must meet the requirements of this study to be selected which must show statistically evidenced and implied metacognitive inventory that has been recognized. Articles are selected after going through the steps such as Identification, Screening, Eligibility and Included.

Search through databases such as Google Scholar, Researchgate, ERIC, SpringerLink, Elsevier, and some other databases, begins with keywords such as mathematical problem-solving skills and metacognitive skills separately and then they are combined into metacognitive skills in mathematical problem solving to prevent journals and non-focused articles from being displayed. However, the journals and articles found are quite limited and the keywords subsequently changed to be more general by using metacognitive in mathematical learning. 'Snowballing' methods are also applied to increase the number of journals and articles funding [2], but the main requirements remain. 12 qualified and selected articles will be analyzed. The following table shows an analysis of the application of metacognitive skills and their effect on students' learning. 
Table 1. Analysis of Application Aspect and Effect of Metacognitive Skills in Mathematics Learning

\begin{tabular}{|c|c|c|c|c|c|c|}
\hline Author(s) & & Research Objective(s) & & Application aspect of MS & & Effect of MS \\
\hline $\begin{array}{l}\text { Kazemi, Fadaee \& Bayat [7] } \\
\text { A Subtle View to Metacognitive Aspect } \\
\text { of Mathematical Problems } \\
\text { Solving } \\
\text { Procedia Social and Behavioral Sciences } \\
8(2010) 420-426\end{array}$ & i. & $\begin{array}{l}\text { To assess the role of metacognitive skills in } \\
\text { mathematical problems solving }\end{array}$ & $\begin{array}{l}\text { ii. } \\
\text { iii. } \\
\text { iv. } \\
\text { v. } \\
\text { vi. }\end{array}$ & $\begin{array}{l}\text { Starting with planning the task } \\
\text { Clarifying task and activities requirements } \\
\text { Always reviewing on progress } \\
\text { Always checking the error } \\
\text { Detecting new development }\end{array}$ & $\begin{array}{l}\text { vii. } \\
\text { viii. }\end{array}$ & $\begin{array}{l}\text { High mathematics problem-solving } \\
\text { performance } \\
\text { Students are cautious to understand the } \\
\text { relationships between the facts in a } \\
\text { problem } \\
\text { Students are checking for accuracy } \\
\text { Students monitor the process of } \\
\text { problem-solving step by step }\end{array}$ \\
\hline $\begin{array}{l}\text { Nongtodu \& Bhutia [26] } \\
\text { Metacognition And Its Relation With } \\
\text { Academic Achievement Among } \\
\text { College-Going Students Of Meghalaya } \\
\text { International Journal of Education and } \\
\text { Psychological Research (IJEPR) Volume } \\
\text { 6, Issue 2, June } 2017\end{array}$ & ii. & $\begin{array}{l}\text { To study the metacognition among } \\
\text { college-going students of Meghalaya } \\
\text { To explore whether metacognition is related } \\
\text { to academic achievement, gender, streams of } \\
\text { discipline and locale }\end{array}$ & $\begin{array}{l}\text { i. } \\
\text { ii. } \\
\text { iii. } \\
\text { iv. } \\
\text { v. }\end{array}$ & $\begin{array}{l}\text { Looking at the problems orientation } \\
\text { Planning the task } \\
\text { Monitoring and testing the strategies' used } \\
\text { Repairing while meet the confuse } \\
\text { Evaluating and reflecting }\end{array}$ & ii. & $\begin{array}{l}\text { Students visualize the thinking } \\
\text { processes such as self-concept of } \\
\text { knowledge, } \\
\text { self-memory, attention } \\
\text { Students build positive study habits }\end{array}$ \\
\hline $\begin{array}{l}\text { Desoete \& Roeyers [24] } \\
\text { Metacognitive Macroevaluations In } \\
\text { Mathematical } \\
\text { Problem Solving } \\
\text { Learning and Instruction } 16 \quad \text { (2006) } \\
\text { 12e25 }\end{array}$ & i. & $\begin{array}{l}\text { To understand the functioning of the } \\
\text { task-specific or micro-metacognitive skills } \\
\text { on mathematical problem solving }\end{array}$ & $\begin{array}{l}\text { i. } \\
\text { ii. } \\
\text { iii. }\end{array}$ & $\begin{array}{l}\text { Planning and working according to the plan } \\
\text { Changing the plan } \\
\text { Reflecting in advance on how difficult this } \\
\text { exercise will be }\end{array}$ & $\begin{aligned} & \text { i. } \\
& \text { ii. }\end{aligned}$ & $\begin{array}{l}\text { Students more alert with accuracy } \\
\text { Students more focus on working and } \\
\text { solutions }\end{array}$ \\
\hline $\begin{array}{l}\text { Phi [3] } \\
\text { Developing Students' Metacognitive } \\
\text { Skills } \\
\text { In Mathematics Classroom } \\
\text { Annals. Computer Science Series. 15th } \\
\text { Tome 1st Fasc. - } 2017\end{array}$ & ii. & $\begin{array}{l}\text { To present the importance of metacognition } \\
\text { to the learning of mathematics employed } \\
\text { metacognitive skills in the process of solving } \\
\text { mathematics problems } \\
\text { To build a theoretical model of } \\
\text { metacognition in Mathematics within the } \\
\text { context of problem-solving among the junior } \\
\text { Mathematics major students of Le Hong } \\
\text { Phong high school, Dong Nai province, } \\
\text { Vietnam }\end{array}$ & i. & $\begin{array}{l}\text { Making reflections on what went on their } \\
\text { minds and what they thought about }\end{array}$ & $\begin{array}{l}\text { i. } \\
\text { ii. } \\
\text { iii. } \\
\text { iv. }\end{array}$ & $\begin{array}{l}\text { Students become comfortable with } \\
\text { strategies } \\
\text { Students employ the strategies } \\
\text { automatically to learning tasks } \\
\text { Students more focusing on their } \\
\text { attention, deriving meaning } \\
\text { Students make adjustments if something } \\
\text { goes wrong }\end{array}$ \\
\hline
\end{tabular}




\begin{tabular}{|c|c|c|c|c|c|c|}
\hline $\begin{array}{l}\text { Smith \& Mancy [8] } \\
\text { Exploring The Relationship Between } \\
\text { Metacognitive } \\
\text { And Collaborative Talk During Group } \\
\text { Mathematical } \\
\text { Problem-Solving - What Do We Mean } \\
\text { By Collaborative Metacognition? } \\
\text { Research in Mathematics Education } \\
\text { 20:1,14-36 }\end{array}$ & i. & $\begin{array}{l}\text { To enhance understanding of the relationship } \\
\text { between collaborative talk and metacognitive talk } \\
\text { during group mathematical problem-solving. }\end{array}$ & $\begin{array}{l}\text { i. } \\
\text { ii. } \\
\text { iii. } \\
\text { iv. } \\
\text { v. }\end{array}$ & $\begin{array}{l}\text { Using the metacognitive skill of monitoring } \\
\text { the interactions of peers } \\
\text { Displaying metacognitive knowledge about } \\
\text { the problem and presenting a strategy } \\
\text { Questioning another's thinking and inviting } \\
\text { them to justify their answer } \\
\text { Displaying metacognitive monitoring by } \\
\text { seeking clarification } \\
\text { Inviting the others in the group to engage in } \\
\text { discussion regarding their strategy use }\end{array}$ & ii. & $\begin{array}{l}\text { Students with much more advanced } \\
\text { metacognitive process patterns are more } \\
\text { involved in discussions and subsequent } \\
\text { solutions. } \\
\text { During the problem-solving exercise, } \\
\text { students with higher metacognitive } \\
\text { awareness have more influence }\end{array}$ \\
\hline $\begin{array}{l}\text { Van der Stel, Veenman, } \\
\text { Deelen \& Haenen [15] } \\
\text { The Increasing Role Of Metacognitive } \\
\text { Skills In Math: } \\
\text { A Cross-Sectional Study From A } \\
\text { Developmental Perspective } \\
\text { ZDM Mathematics Education (2010) } \\
\text { 42:219-229 }\end{array}$ & ii. & $\begin{array}{l}\text { To investigate the development of metacognitive } \\
\text { skillfulness during math performance in } \\
\text { particular } \\
\text { To investigate the relation between } \\
\text { metacognitive skills, intellectual ability, and } \\
\text { learning performance in math from a } \\
\text { developmental perspective }\end{array}$ & $\begin{array}{l}\text { i. } \\
\text { ii. } \\
\text { iii. } \\
\text { iv. } \\
\text { v. } \\
\text { vi. } \\
\text { vii. }\end{array}$ & $\begin{array}{l}\text { Estimating the answer } \\
\text { Sketching the problem to represent the } \\
\text { problem } \\
\text { Designing a step-by-step action plan, } \\
\text { instead of working by trial and error } \\
\text { Monitoring action plan } \\
\text { Checking an answer by recalculating } \\
\text { Paraphrasing the problem } \\
\text { vii. Concluding while referring to the } \\
\text { problem statement }\end{array}$ & $\begin{array}{l}\text { ii. } \\
\text { iii. }\end{array}$ & $\begin{array}{l}\text { Students become more selective in their } \\
\text { orientation activities over the years, } \\
\text { resulting in fewer, but perhaps better, } \\
\text { orientation activities } \\
\text { Students increase the number of their } \\
\text { elaboration activities } \\
\text { Students seem to experience a problem } \\
\text { in abstracting knowledge }\end{array}$ \\
\hline $\begin{array}{l}\text { Su, Ricci \& Mnatsakanian [27] } \\
\text { Mathematical Teaching Strategies: } \\
\text { Pathways to Critical Thinking and } \\
\text { Metacognition } \\
\text { International Journal of Research in } \\
\text { Education and Science, Volume 2, Issue } \\
\text { 1, Winter } 2016\end{array}$ & i. & $\begin{array}{l}\text { To indicate the necessity of applying critical } \\
\text { thinking and provide an example of how critical } \\
\text { thinking, creativity and flexibility in finding such } \\
\text { ways help students to better understand the } \\
\text { concepts of number sense }\end{array}$ & $\begin{array}{l}\text { ii. } \\
\text { iii. } \\
\text { iv. } \\
\text { v. }\end{array}$ & $\begin{array}{l}\text { Identifying possible conclusions and } \\
\text { selecting logical conclusions } \\
\text { Describing how a solution was presented } \\
\text { Identifying scenarios and evaluating } \\
\text { Selecting problem-solving strategies } \\
\text { Indicating how those solutions can be } \\
\text { applied to more advanced math problems }\end{array}$ & $\begin{array}{l}\text { iii. } \\
\text { iv. }\end{array}$ & $\begin{array}{l}\text { Students become confident critical } \\
\text { thinkers } \\
\text { Developing critical thinking and } \\
\text { reasoning allows students to think } \\
\text { about how they utilize their discipline of } \\
\text { mathematical skills } \\
\text { Ensuring students to think about their } \\
\text { method of thinking } \\
\text { Developing the ability to analyze, } \\
\text { prepare and strategize is described as } \\
\text { key aspects of organizational } \\
\text { achievement, decision-making, and life } \\
\text { choices } \\
\text { Metacognition helps students to } \\
\text { recognize that math is logical reasoning } \\
\text { on solutions to problems }\end{array}$ \\
\hline
\end{tabular}




\begin{tabular}{|c|c|c|c|c|c|c|}
\hline $\begin{array}{l}\text { Shaw [28] } \\
\text { The Effects Of Metacognitive } \\
\text { Awareness On The Development Of } \\
\text { Mathematical Problem-Solving } \\
\text { Skills In Fourth-Grade Homework } \\
\text { Assignments } \\
\text { Education and Educational Psychology, } \\
\text { Spring 5-2008 }\end{array}$ & & $\begin{array}{l}\text { To investigate the effects of metacognitive } \\
\text { awareness on the development of } \\
\text { problem-solving skills when metacognitive } \\
\text { awareness practice was included as a part of } \\
\text { mathematical problem-solving skills for } \\
\text { homework assignments of fourth-grade } \\
\text { students. }\end{array}$ & $\begin{array}{l}\text { i. } \\
\text { ii. } \\
\text { iii. } \\
\text { iv. } \\
\text { v. }\end{array}$ & $\begin{array}{l}\text { Awareness of how much learning can be } \\
\text { controlled } \\
\text { Working constantly to choose suitable } \\
\text { strategies } \\
\text { Monitoring the strategy used throughout } \\
\text { the learning process } \\
\text { Tending to continue in a job or task until } \\
\text { they are satisfied with it } \\
\text { Attributing success to students ' efforts }\end{array}$ & i. & $\begin{array}{l}\text { Ensuring that students are mindful of } \\
\text { themselves, the task and the strategies } \\
\text { that are available when entering a } \\
\text { learning activity }\end{array}$ \\
\hline $\begin{array}{l}\text { Tony Karnain, et. al [12] } \\
\text { Exploring the Metacognitive Skills of } \\
\text { Secondary School Students' Use } \\
\text { During Problem Posing } \\
\text { Jurnal } \\
\text { Teknologi } \\
\text { (Social Sciences) } 67: 1 \text { (2014) 27-32 }\end{array}$ & i. & $\begin{array}{l}\text { To explore students' use of metacognitive skills } \\
\text { during problem-posing activities }\end{array}$ & $\begin{array}{l}\text { iv. } \\
\text { v. } \\
\text { vi. }\end{array}$ & $\begin{array}{l}\text { Making good sense of the task, extracting } \\
\text { the information given, and being aware of } \\
\text { the purpose } \\
\text { Seeking any examples used in the past, and } \\
\text { mapping a solution } \\
\text { Linking and identifying the previous } \\
\text { strategies that are relevant to the current } \\
\text { problem } \\
\text { Monitoring with screened for errors, } \\
\text { justifying their judgments and making } \\
\text { revisions to correct wrong turns } \\
\text { Alluding to the need to revise their } \\
\text { approach } \\
\text { Always checking the answers being right or } \\
\text { wrong }\end{array}$ & i. & $\begin{array}{l}\text { Students are proposing alternate solutions } \\
\text { and reflecting on what new things they } \\
\text { learned by attempting the problem. }\end{array}$ \\
\hline
\end{tabular}




\begin{tabular}{|c|c|c|c|c|c|c|}
\hline $\begin{array}{l}\text { Tzohar-Rozen \& Kramarski [17] } \\
\text { Metacognition, Motivation, and } \\
\text { Emotions: } \\
\text { Contribution of Self-Regulated } \\
\text { Learning to Solving Mathematical } \\
\text { Problems } \\
\text { Global Education Review, } 1 \text { (4). 76-95. }\end{array}$ & i. & $\begin{array}{l}\text { To develop, examine, and compare two SRL } \\
\text { interventions dealing with two components of } \\
\text { self-regulation: metacognitive regulation (MC) } \\
\text { and motivational-emotional regulation (ME) }\end{array}$ & $\begin{array}{l}\text { i. } \\
\text { ii. } \\
\text { iii. } \\
\text { iv. } \\
\text { v. } \\
\text { vi. }\end{array}$ & $\begin{array}{l}\text { Planning and allocating resources for } \\
\text { learning } \\
\text { Monitoring their knowledge and skills } \\
\text { Reviewing their performance levels during } \\
\text { learning acquisition at different points } \\
\text { Planning includes finding the right strategies } \\
\text { and allocating resources that affect } \\
\text { performance } \\
\text { Monitoring relations to the awareness of } \\
\text { students of their understanding and quality of } \\
\text { performance while carrying out tasks } \\
\text { Evaluation referring to assessing the } \\
\text { outcomes and methods of learning. }\end{array}$ & i. & $\begin{array}{l}\text { Ability to transfer the skills they had } \\
\text { learned to a new task } \\
\text { The goal of metacognitive regulation is to } \\
\text { enhance learning skills by providing } \\
\text { learners with structured and explicit } \\
\text { feedback as they think and reflect on their } \\
\text { tasks }\end{array}$ \\
\hline $\begin{array}{l}\text { Abdullah, } \\
\text { Rahman \& Hamzah [6] } \\
\text { Metacognitive Skills of Malaysian } \\
\text { Students in Non-Routine Mathematical } \\
\text { Problem Solving } \\
\text { Bolema, Rio Claro (SP), v. 31, n. 57, p. } \\
310 \text { - 322, abr. } 2017\end{array}$ & i. & $\begin{array}{l}\text { To identify students' metacognitive skills and the } \\
\text { impact of such skills on non-routine mathematical } \\
\text { problem solving }\end{array}$ & $\begin{array}{r}\text { i. } \\
\text { ii. } \\
\text { iii. }\end{array}$ & $\begin{array}{l}\text { Translating information into an } \\
\text { understandable form } \\
\text { Considering alternative solutions } \\
\text { Revising the steps for the solution }\end{array}$ & i. & $\begin{array}{l}\text { Metacognitive skill awareness can boost } \\
\text { interest in the learning process }\end{array}$ \\
\hline $\begin{array}{l}\text { Amin \& Sukestiyarno [13] } \\
\text { Analysis Metacognitive Skills } \\
\text { On Learning Mathematics In High } \\
\text { School } \\
\text { International Journal of Education and } \\
\text { Research Vol. } 3 \text { No. } 3 \text { March } 2015\end{array}$ & $\begin{array}{l}\text { ii. } \\
\text { iii. }\end{array}$ & $\begin{array}{l}\text { To extend the metacognitive awareness of high } \\
\text { school students when answering a series of } \\
\text { questions metacognitive on mathematics } \\
\text { learning } \\
\text { To see the influence of metacognitive } \\
\text { awareness of the cognitive skills and } \\
\text { metacognitive skills } \\
\text { To study the relationship between cognitive } \\
\text { skills and metacognitive skills }\end{array}$ & $\begin{array}{l}\text { i. } \\
\text { ii. } \\
\text { iii. } \\
\text { iv. } \\
\text { v. }\end{array}$ & $\begin{array}{l}\text { Understanding what the problem is about- } \\
\text { the planning process solutions and choosing } \\
\text { the right strategy and the stage of deciding } \\
\text { whether it makes sense or not } \\
\text { Managing and process information by } \\
\text { organizing, outlining, summarizing, selective } \\
\text { focus } \\
\text { Drawings or diagrams to enhance their } \\
\text { understanding } \\
\text { Mapping the concepts to help to understand } \\
\text { Making a summary of what they learned. }\end{array}$ & ii. & $\begin{array}{l}\text { Increasing the ability to recall } \\
\text { information and the ability to judge for } \\
\text { themselves on their ability to understand } \\
\text { something } \\
\text { The student has sufficient ability to } \\
\text { perform self-assessment of learning or } \\
\text { to assess the strategies it uses } \\
\text { The student has sufficient capability of } \\
\text { controlling thinking or learning, and } \\
\text { building a meaningful theory on their } \\
\text { cognition } \\
\text { The student has a good ability to plan, } \\
\text { set goal, and allocate resources before } \\
\text { learning }\end{array}$ \\
\hline
\end{tabular}




\section{Finding and Discussion}

Twelve qualifying studies have been reviewed and the findings will be discussed based on the research questions.

\subsection{What Are Metacognitive Skills That Students Applied during the Mathematical Problem-Solving Task?}

Based on the findings of the study, it is found that the aspects of metacognitive skills are applied and always practiced while solving mathematical problems. However, there are more aspects of metacognitive skills practiced. The following is an interpretation of findings according to the basic steps in solving mathematical problems.
Based on the results of Table 2, it can be concluded that, while solving mathematical problems, students will practice metacognitive skills according to appropriate chronology. However, this study can explain that the practice of metacognitive skills is specific, that the metacognitive knowledge aspect is applied at the initial stage of problem-solving and so metacognitive regulation aspects will take over the entire process and subsequent actions. This coincides with the fact by Tariccone [18] who explains that metacognitive regulation is a secondary cluster in the thinking taxonomy and is an intermittent act of thinking. This is illustrated by Schraw \& Moshman [14], Shaw [28] and Desoete \& Roeyers [24]who said that knowledge and regulations can move together but will have different effects.

Table 2. A Meta-analysis of Metacognitive Skills Involved during Problem Solving Activities

\begin{tabular}{|c|c|c|c|}
\hline \multicolumn{2}{|c|}{ Problem Solving Steps / Skills } & $\begin{array}{ll}\text { Metacognitive } & \text { Skills } \\
\text { Aspect Involved } & \end{array}$ & Reported Researcher(s) \\
\hline \multicolumn{2}{|c|}{$\begin{array}{ll}\text { Understand the problem } \\
\text { i. } & \text { Clarifying the problem } \\
\text { ii. } & \text { Looking at problem orientation } \\
\text { iii. } & \text { Seeking any example used in the past } \\
\text { iv. } & \text { Translating the problem statement to own words }\end{array}$} & $\begin{array}{l}\text { Declarative } \\
\text { Procedural } \\
\text { Planning }\end{array}$ & $\begin{array}{l}\text { Kazemi, Fadaee \& Bayat [7], Nongtodu \& } \\
\text { Bhutia [26], Desoete \& Roeyers [24], Tony } \\
\text { Karnain et. al [12], Abdullah, } \\
\text { Rahman \& Hamzah [6], Amin \& } \\
\text { Sukestiyarno [13] }\end{array}$ \\
\hline $\begin{array}{r}D e \\
\text { i. } \\
\text { ii. } \\
\text { iii. } \\
\text { iv. } \\
\text { v. } \\
\text { vi. } \\
\text { vii. } \\
\text { viii. } \\
\text { ix. }\end{array}$ & $\begin{array}{l}\text { plan } \\
\text { Planning the work } \\
\text { Sketching problems } \\
\text { Setting the goals } \\
\text { Designing the steps } \\
\text { Paraphrasing the problem } \\
\text { Identify possible conclusion/answer } \\
\text { Seting the possible strategies } \\
\text { Relating to previous solutions/tasks } \\
\text { Mapping the plan }\end{array}$ & $\begin{array}{l}\text { Conditional } \\
\text { Planning } \\
\text { Monitoring }\end{array}$ & $\begin{array}{l}\text { Kazemi, Fadaee \& Bayat [7], Nongtodu \& } \\
\text { Bhutia [26], Desoete \& Roeyers [24], Phi [3], } \\
\text { Smith \& Mancy [8], Van der Stel, Veenman, } \\
\text { Deelen \& Haenen [15], Su, Ricci \& } \\
\text { Mnatsakanian [27], Tzohar-Rozen \& } \\
\text { Kramarski [17], Amin \& Sukestiyarno [13] }\end{array}$ \\
\hline $\begin{array}{r}C a \\
\text { i. } \\
\text { ii. } \\
\text { iii. } \\
\text { iv. } \\
\text { v. } \\
\text { vi. }\end{array}$ & $\begin{array}{l}\text { It of the plan } \\
\text { Operating the plan } \\
\text { Testing the strategies } \\
\text { Working on selected strategies } \\
\text { Reviewing on progress } \\
\text { Repairing when meet the confuse } \\
\text { On the alternative way if need }\end{array}$ & $\begin{array}{l}\text { Planning } \\
\text { Monitoring } \\
\text { Evaluating }\end{array}$ & $\begin{array}{l}\text { Kazemi, Fadaee \& Bayat [7], Nongtodu \& } \\
\text { Bhutia [26], Desoete \& Roeyers [24], Smith } \\
\text { \& Mancy [8], Su, Ricci \& Mnatsakanian [27], } \\
\text { Shaw [28], Abdullah, } \\
\text { Rahman \& Hamzah [6], Amin \& } \\
\text { Sukestiyarno [13] }\end{array}$ \\
\hline $\begin{array}{r}\text { Lo } \\
\text { i. } \\
\text { ii. } \\
\text { iii. } \\
\text { iv. } \\
\text { V. }\end{array}$ & $\begin{array}{l}\text { ck/Reflection } \\
\text { Evaluating } \\
\text { Reflecting } \\
\text { Detecting new develop } \\
\text { Reflecting in advance on how difficult } \\
\text { Recalculating the solutions }\end{array}$ & $\begin{array}{l}\text { Monitoring } \\
\text { Evaluating }\end{array}$ & $\begin{array}{l}\text { Kazemi, Fadaee \& Bayat [7], Nongtodu \& } \\
\text { Bhutia [26], Desoete \& Roeyers [24], Phi [3], } \\
\text { Van der Stel, Veenman, Deelen \& Haenen } \\
\text { [15], Tony Karnain et. al [12], Amin \& } \\
\text { Sukestiyarno [13] }\end{array}$ \\
\hline
\end{tabular}


Researchers such as Hasbullah [4], Phi [3], Shaw [28], Nongtodu \& Bhutia [26], Desoete \& Roeyers [24] and Su, Ricci \& Mnatsakanian [27] discussed that regulation aspects play a role in and influence the student's mathematical competence. According to Moos \& Ringdals [20], metacognitive regulation begins once the mathematical task is given. It begins with understanding the problem, which involves metacognitive knowledge. For the next, metacognitive regulation will continue the cognitive process by setting goals, designing, selecting strategies, using strategies and concluding by reflecting on such actions $[3,26]$. To understand that needs to ensure that accuracy and completeness in solving mathematical problems require the ability of students to plan, monitor and evaluate their thinking and learning activities.

\subsection{What Is the Effect of Metacognitive Skills on the Student's Learning Performance?}

Furthermore, the findings show that students who can practice and develop metacognitive skills will ensure that they can master the learning. The effect of metacognitive skills can be seen from two points of view which is the mastery of student concepts and the students' mathematical competencies. The following researchers report that metacognitive skills have a significant relationship with the mastery of the students, especially in solving mathematical problems. The studies conducted by Phi [3], Nongtodu \& Bhutia [26], Desoete \& Roeyers [24] and Tzohar-Rozen \& Kramaski [17] show that there is a positive relationship between metacognitive skills, grades and achievements through the strategies implemented. This is because according to Schraw \& Moshman [14] and Du Toit \& Du Toit [5], metacognitive knowledge and regulations drive students to set the learning goals, plan, select strategies, monitor learning processes, and evaluate their learning outcomes. Through this metacognitive skill, thinking efficiency will increase and thus this skill will affect the students' understanding of the concept in parallel with studies of Du Toit \& Kotze [22], Smith [16] and Warner \& Kaur [1].

As reported by Kazemi, Fadaee \& Bayat [7], Nongtodu \& Bhutia [26], Desoete \& Roeyers [24], Tzohar-Rozen \& Kramaski [17] and Tony Karnain et. al [12] students who are given enough metacognitive skills training will always understand the relationships among the facts in a problem, allocate resources before learning, check themselves for accuracy, visualize the thinking processes such as self-concept of knowledge, self-intelligence, self-memory, attention, make adjustments if something goes wrong and so on. Thus, this result clearly shows that the student's mathematical competency has increased. Metacognitive knowledge opens up students' interest and emotional spaces towards looking at more specific problem orientation [17], while metacognitive regulation moves the hands-on and mind-on aspect of students to drive and build new knowledge when success in problem-solving achieved [3]. Metacognitive skills play a lot of roles in ensuring students can master mathematics and have better mathematical problem-solving skills.

\section{Conclusions and Recommendation}

To implement effective mathematical learning, metacognitive skills need to be provided with training and applied to improve students' performance and thinking skills which in turn lead to the mastery of mathematical concepts. Therefore, teachers and responsible parties need to provide a learning medium that can create a conducive learning environment that provides opportunities for students to develop metacognitive skills. This is because metacognitive skills can be affected and influence the mastery of the mathematical concept of the students. As a suggestion, the stakeholders or researchers will come up with an approach that implements metacognitive skills to transform conventional teaching practices into active learning practices that provide more opportunities for students to manage their learning naturally and on their own needs for examples, through knowledge, experience, and metacognitive regulation.

Through the literature discussed, some researchers suggest the need for an approach that implements knowledge of metacognitive skills to be in line with the technological developments and the transformation of the current curriculum. In fact, it generates learning kits, modules, models and applications to ensure students get real compatibility. It can be concluded that metacognitive skills are not only important to influence mathematical mastery, but also can affect the formation of students' attitudes and behavior towards mathematical subjects. This study should also have a continuing study on the impact of metacognitive skills and how to produce metacognitive learning strategies.

\section{REFERENCES}

[1] Warner, S \& Kaur, A. (2017). The Perceptions of Teachers and Students on 21st Century Mathematics Instructional Model. International Electronic Journal of Mathematics Education, Vol. 12, No. 2, 193-215.

[2] Izzati, L.R. \& Mahmudi, A. (2018). The Influence of Metacognition in Mathematical Problem Solving. IOP Conf. Series: Journal of Physics: Conf. Series, 1097 (2018), 1-7. doi:10.1088/1742-6596/1097/1/012107

[3] Phi, V.T. (2017). Developing Students' Metacognitive Skills in Mathematics Classroom. Annals. Computer Science Series, 15 (1), 41-46.

[4] Hasbullah (2015). The Effect of Ideal Metacognitif Strategy on Achievement in Mathematics. International Journal of 
Educational Research and Technology, 6(4), 42-45. doi: 10.15515/ijert.0976-4089.6.4.4245

[5] Du Toit, S.D. \& Du Toit, G.F. (2013). Learner Metacognition and Mathematics Achievement during Problem-Solving in a Mathematics Classroom. TD The Journal for Transdisciplinary Research in Southern Africa, 9(3), Special edition, December 2013, 505-518.

[6] Abdullah, A.H., Rahman, S.N.S.A. \& Hamzah, M.H. (2017). Metacognitive Skills of Malaysian Students in Non-Routine Mathematical Problem Solving. Bolema, Rio Claro (SP), v. 31 , n. 57, pp $310-322$.

[7] Kazemi, F., Fadaee, M.R. \& Bayat, S. (2010). A Subtle View to Metacognitive Aspect of Mathematical Problems Solving. Procedia Social and Behavioral Sciences, 8 (2010), 420-426

[8] Smith, J.M \& Mancy, R. (2018). Exploring the Relationship between Metacognitive and Collaborative Talk During Group Mathematical Problem-solving - What do We Mean by Collaborative Metacognition? Research in Mathematics Education, 20(1), 14-36. doi: 10.1080/14794802.2017.141 0215.

[9] Adnan \& Arsad Bahri (2018). Beyond Effective Teaching: Enhancing Students' Metacognitive Skill through Guided Inquiry. IOP Publishing Journal of Physics: Conf. Series, 954 (2018), 012-022. doi:10.1088/1742- 6596/954/1/01202 2.

[10] Menz, P. \& Cindy Xin (2016).Making Students' Metacognitive Knowledge Visible through Reflective Writing in a Mathematics-for-Teachers Course. Collected Essays on Learning and Teaching, Simon Fraser University, Vol. IX, 155-166.

[11] Stephanou, G. \& Mpiontini, M. (2017). Metacognitive Knowledge and Metacognitive Regulation in Self-Regulatory Learning Style, and Its Effects on Performance Expectation and Subsequent Performance across Diverse School Subjects. Psychology, 8, 1941-1975. doi.org/10.42 36/psych.2017.812125.

[12] Tony Karnain, Bakar, M.N., Siamakani, S.Y.M., Mohammadikia, H. \& Candra, M. (2014). Exploring the Metacognitive Skills of Secondary School Students' Use during Problem Posing. Jurnal Teknologi (Social Sciences), 67(1), 27-32

[13] Amin, I. \& Sukestiyarno, Y.L. (2015). Analysis Metacognitive Skills on Learning Mathematics in High School. International Journal of Education and Research, Vol. 3 No. 3, 213-222.

[14] Schraw, G. \& Moshman, D. (1995). Metacognitive Theories. Educational Psychology Papers and Publications, 40. Online: http://digitalcommons.unl.edu/edpsychpapers/40

[15] Van Der Stel, M., Veenman, M.V.J., Deelen, K. \& Haenen, J. (2010). The Increasing Role of Metacognitive Skills in Math: A Cross-sectional Study from a Developmental Perspective. ZDM Mathematics Education, 42, 219-229. doi: 10.1007/s11858-009-0224-2

[16] Smith, M.J. (2013). An Exploration of Metacognition and its Effect on Mathematical Performance in Differential Equations. Journal of the Scholarship of Teaching and Learning, Vol. 13, No. 1, 100-111.
[17] Tzohar-Rozen, M. \& Kramarski, B. (2014). Metacognition, Motivation, and Emotions: Contribution of Self-Regulated Learning to Solving Mathematical Problems. Global Education Review, 1 (4), 76-95.

[18] Tarricone, P. (2011). The Taxonomy of Metacognition. New York, NY, US: Psychology Press. E-Book: http://libraryop ac.utm.my.

[19] Van Der Walt, M.S., Maree, J.G. \& Ellis, S.M. (2008). Metacognition in the Learning of Mathematics in the Senior Phase: Some Implications for the Curriculum. International Journal of Adolescence and Youth, 14(3), 205-235.

[20] Moos, D.C. \& Ringdal, A. (2012). Self-Regulated Learning in the Classroom: A Literature Review on the Teacher's Role. Education Research International, Volume 2012, 1-15. doi:10.1155/2012/423284.

[21] Ahmad, H., Febryanti, Fatimah \& Muthmainnah (2018). Description of Student's Metacognitive Ability in Understanding and Solving Mathematics Problem. 4th International Conference on Operational Research (InteriOR), IOP Conf. Series: Materials Science and Engineering, 300 (2018). doi:10.1088/1757- 899X/300/1/0 12048 .

[22] Du Toit, S.D. \& Kotze (2009).Metacognitive Strategies in the Teaching and Learning of Mathematics. Pythagoras Journal, 70, 57-67.

[23] Cera, R., Mancini, M. \& Antonietti, A. (2013). Relationship Between Metacognition,Self-Efficacy and Self-Regulation in Learning. ECPS-Journal, 7/2013, 115-141. doi: 10.7358/ ecps-2013-007-cera.

[24] Desoete, A. \& Roeyers, H. (2006). Metacognitive Macroevaluations in Mathematical Problem Solving. Learning and Instruction, 16 (2006), 12-25

[25] Moher, D., Liberati, A., Tetzlaff, J. \& Altman, D.G. (2009) Preferred Reporting Items for Systematic Reviews and Meta-Analyses: The PRISMA Statement. PLoS Med, 6(7), 1-6. doi:10.1371/journal.pmed.1000097

[26] Nongtodu, S. \& Bhutia, Y. (2017). Metacognition and its Relation with Academic Achievement among College Going Students of Meghalaya. International Journal of Education and Psychological Research (IJEPR), Volume 6, Issue 2, 54-60.

[27] Su, H.F., Ricci, F.A., \& Mnatsakanian, M. (2016) Mathematical Teaching Strategies: Pathways to Critical Thinking and Metacognition. Journal of Research in Education and Science (IJRES), 2 (1), 190-200.

[28] Shaw, S.C. (2008). The Effects of Metacognitive Awareness on the Development of Mathematical Problem-Solving Skills in Fourth-Grade Homework Assignments. Education and Educational Psychology, Spring 5-2008. 